\title{
A Study on Socio-Economic Aspects and Flock Composition of Shepherds in Irrigated and Rainfed Areas in Krishna District of Andhra Pradesh, India
}

\author{
Sai Satish Raju Sarikonda ${ }^{1 *}$, Asha Latha Peeka ${ }^{1}$, \\ Sudhakar Kaza ${ }^{1}$ and Raja Kishore Konka ${ }^{2}$
}

${ }^{1}$ Department of Livestock Production Management, ${ }^{2}$ Department of Animal Nutrition, NTR College of Veterinary Science, Gannavaram--521101, Andhra Pradesh, India

*Corresponding author

\section{Keywords}

Sheep, Socio-

Economic profile,

Flock composition,

Krishna district

Article Info

Accepted:

22 April 2021

Available Online:

10 May 2021

\section{A B S T R A C T}

Present study was conducted on 250 shepherds selected through multistage stratified random sampling technique in irrigated and rainfed areas in Krishna district of Andhra Pradesh. Out of the total farmers surveyed, illiterate sheep farmers constituted about 81.6 and 88 percent in irrigated and rainfed areas, respectively. Sheep farmers from Backward Communities constituted about 86.4 and 67.2 percent, followed by Scheduled Castes community 8 percent and 15.20 percent, respectively, in irrigated and rainfed areas. Majority of the farmers in both the areas were landless (45.6 percent in irrigated area and 72.8 percent in rainfed area) followed by marginal land holders (36 percent in irrigated area and 16.8 percent in rainfed area). About 64 percent shepherds in irrigated area and 60 percent shepherds in rainfed area were middle aged. The average flock size in irrigated and rainfed areas of the district was $66.36 \pm 2.32$ and 73.62 \pm 3.0 , respectively. Most of the farmers in irrigated area (54.4 percent) and rainfed area (68 percent) reared sheep along with goats. Replacement stock from their own flock was the main source of addition to the sheep flocks of both the areas.

\section{Introduction}

The livestock play a pivotal role in the country's rural economy. The sheep and goat in India are mostly reared by the landless laborers and marginal farmers, who are considered as the socially and economically disadvantaged sections in the rural society. In the event of failure of seasonal rains leading to crop failure, rearing of these small ruminants gives a helping hand to the farmers. It provides gainful employment and income to the weaker sections especially to the rural poor. The small ruminants suite the need of 
small land holders and village system due to low initial investment, ease of rearing and high feed conversion efficiency. Besides this, they are very well adapted to harsh climate, long migration, resistance against tropical diseases, poor nutrition, shortage of drinking water and water quality. Sheep rearing is acting as a source of livelihood, nutritional security and also as a moving asset, which can be liquidated during crisis periods within short time. Inspite of the animal potentials, the farmers who are engaged in sheep husbandry were ignorant of modern scientific management practices. Age, education, caste, land-holding and size of family have great influence on adoption of modern management practices. So it is imperative to know the socio-economic profile of the shepherds. Keeping in this view in mind the present study was undertaken to study the socio-economic aspects and flock composition in the sheep flocks of irrigated and rainfed areas in Krishna district of Andhra Pradesh.

\section{Materials and Methods}

The present study was conducted in the Krishna district of Andhra Pradesh. Selection of respondents was made by multistage stratified random sampling technique. The district is divided into two areas i.e irrigated and rainfed areas. In the first stage from each area, five mandals were selected. In the second stage from each mandal, five villages were selected at random. In the third stage from each selected village, 5 sheep farmers were selected forming total respondents of 250 farmers. Based on above classification, the study involved a total number of 2 areas, 10 mandals, 50 villages and 250 farmers. The information pertaining to sheep farmers regarding the level of literacy based on the ability to read and write was collected. The chronological age at the time of inquiry was taken as a measure and classified into three categories as young, middle and old. Flock size had been formulated considering the number of heads of sheep which included ram, ewe, replacement female and lambs possessed by the flock owners and the average flock size per household was calculated. Sheep farming experience was also calculated based on the observations in the questionnaire. The data collected were subjected to standard statistical procedures as per Snedecor and Cochran (1994) and using SPSS (version 15.0.1) software.

\section{Results and Discussion}

Most of the farmers studied in the irrigated and rainfed areas of Krishna district were middle-aged (64 percent and 60 percent respectively). About 14.4 percent farmers are of young age in both irrigated and rainfed areas. Whereas, $21.6 \%$ and $25.6 \%$ of the farmers were of old age in irrigated and rainfed areas, respectively. The percentage of young people involved in the sheep rearing was very low. It indicates that youth was not showing any interest towards sheep rearing. Illiterate sheep farmers constituted about 81.6 and 88 percent in irrigated and rainfed areas of the study area, respectively. The results are comparable with previous studies Maheswaran 1998 who reported88 per cent of the sheep holders were illiterates in Mecheri Taluk of Salem District in Tamil Nadu. However in another study, about 70-80 percent Chokla sheep rearers were literates Kushwaha 1999a. This indicates that majority of the farmers in the study area were not having education and were not aware of the importance of education as they entered the sheep rearing by tradition. Therefore, it became a major hindrance for the farmers to adopt scientific methods of rearing and to accept new management practices. Nuclear family type dominated in both the areas (81.6 in irrigated and 84.8 percent in rainfed area), followed by joint family type (18.4 and 15.2 percent, respectively).Majority of the farmers in both the areas were landless 
(45.6 percent in irrigated area and 72.8 percent in rainfed area) followed by marginal land holders (36 percent in irrigated area and 16.8 percent in rainfed area). Small holders constituted about 16.8 percent in irrigated area and 9.6 percent in rainfed area. Very few medium farmers noticed in the study area (1.6 percent in irrigated area and 0.8 percent in rainfed area).

The average land holding size in irrigated area was $1.2 \pm 0.14$ acres and in rainfed area it was $0.60 \pm 0.10$ acres.

Majority of the sheep farmers were having annual household income between Rs. 55,000 $-90,000$ (51.2 percent in irrigated area and 52 percent in rainfed area), followed by the farmers having income below Rs. 55,000 (44.8 percent in irrigated area and 41.6 percent in rainfed area). Very few sheep farmers (4 percent in irrigated and 6.4 percent in rainfed area) were getting income above Rs. 90,000 per year. These figures suggest that the sheep husbandry was still in the hands of economically weaker section of the population.

Most of the sheep farmers were living in kutcha houses (57.6 percent in irrigated area and 56 percent in rainfed area) and remaining sheep farmers were living in pucca houses (42.4 percent in irrigated area and 44 percent in rainfed area).These results indicate the economic backwardness of shepherds in the study area.

In irrigated area, most of the sheep farmers were Hindus (96 percent) followed by Christians (4 percent). No Muslim respondent encountered in the present study in both areas. Similarly, most of the sheep farmers in rainfed area were Hindus (92 percent) followed by Christians (8 percent). Sheep farmers from Backward Communities constituted about 86.4 and 67.2 percent, respectively, in irrigated and rainfed area of the study. Sheep farmers from Scheduled Castes community constituted about 8 and 15.20 percent respectively in the above areas. Sheep farmers from Schedule Tribes community constituted 2.4 and 13.6 percent, respectively, in irrigated and rainfed areas. Very few sheep farmers from other than above said communities (OC) were encountered during the study (3.2 percent in irrigated area and 4 percent in rainfed area). It may be concluded from the results in the present study that sheep farming in the study area was still practiced as a castebased occupation. Most of the sheep farmers in both areas had 5-15 years of experience in sheep farming (60.8 percent in irrigated and 57.6 percent in rainfed area). About 20.8 percent of farmers in irrigated area and 19.2 percent farmers in rainfed area had sheep farming experience of less than 5 years. Sheep farmers having the experience of more than 15 years were 18.4 percent in irrigated area and 23.2 percent in rainfed area. The average sheep farming experience in irrigated area was $9.77 \pm 0.69$ years and in rainfed area it was $12.05 \pm 0.88$ years.

Majority of the farmers in irrigated area (54.4 percent) and rainfed area (68 percent) reared sheep along with goats.

The results indicating that the farmers had knowledge about the advantage of keeping the mixed herd with goats like leading the herd and controlling the sheep herd with the help of goats. It was observed that out of the total farmers studied majority were maintaining flocks whose size ranged between 51-75 (42.4 percent in irrigated area and 32 percent in rainfed area). About 28\% of sheep farmers were maintaining flock with size ranged 2550 , about $19.2 \%$ farmers were maintaining flock ranged in between 76-100, 5.6\% were maintaining flocks above 100 and very few farmers were maintaining less than 25 sheep (4.8 percent) in irrigated area. 
Table.1 Flock profile of shepherds in irrigated and rainfed areas of Krishna district.

\begin{tabular}{|c|c|c|c|c|c|c|c|c|}
\hline \multirow[t]{2}{*}{ S.No. } & \multirow{2}{*}{\multicolumn{2}{|c|}{ Observation }} & \multicolumn{2}{|c|}{ Irrigated area } & \multicolumn{2}{|c|}{ Rainfed area } & \multicolumn{2}{|c|}{ Total } \\
\hline & & & $\begin{array}{c}\text { No. of } \\
\text { farmers }\end{array}$ & $\%$ & $\begin{array}{c}\text { No. of } \\
\text { farmers }\end{array}$ & $\%$ & $\begin{array}{c}\text { No. of } \\
\text { farmers }\end{array}$ & $\%$ \\
\hline \multirow[t]{4}{*}{1} & \multirow{4}{*}{$\begin{array}{c}\text { Livestock } \\
\text { ownership }\end{array}$} & Sheep alone & 16 & 12.8 & 10 & 8 & 26 & 10.4 \\
\hline & & Sheep+goat & 68 & 54.4 & 85 & 68 & 153 & 61.2 \\
\hline & & Sheep+Goat+Buffalo & 36 & 28.8 & 20 & 16 & 56 & 22.4 \\
\hline & & Sheep+Buffalo+Poultry & 5 & 4 & 10 & 8 & 15 & 6 \\
\hline \multirow[t]{5}{*}{2} & \multirow[t]{5}{*}{ Flock size } & $<25$ & 6 & 4.8 & 4 & 3.2 & 10 & 4 \\
\hline & & $25-50$ & 35 & 28 & 30 & 24 & 65 & 26 \\
\hline & & $51-75$ & 53 & 42.4 & 40 & 32 & 93 & 37.2 \\
\hline & & 76-100 & 24 & 19.2 & 33 & 26.4 & 57 & 22.8 \\
\hline & & $>100$ & 7 & 5.6 & 18 & 14.4 & 25 & 10 \\
\hline \multirow[t]{4}{*}{3} & \multirow{4}{*}{$\begin{array}{l}\text { Source of } \\
\text { rams }\end{array}$} & Homegrown & 81 & 64.8 & 66 & 52.8 & 147 & 58.8 \\
\hline & & Purchased & 3 & 2.4 & 4 & 3.2 & 7 & 2.8 \\
\hline & & Exchanged & 41 & 32.8 & 55 & 44 & 96 & 38.4 \\
\hline & & No ram & 0 & 0 & 0 & 0 & 0 & 0 \\
\hline \multirow[t]{2}{*}{4} & \multirow{2}{*}{$\begin{array}{c}\text { Source of } \\
\text { EWES }\end{array}$} & Homegrown & 117 & 93.6 & 115 & 92 & 232 & 92.8 \\
\hline & & Purchased & 8 & 6.4 & 10 & 8 & 18 & 7.2 \\
\hline
\end{tabular}


Table.2 Socio economic profile of shepherds in irrigated and rainfed areas of Krishna district.

\begin{tabular}{|c|c|c|c|c|c|c|c|c|}
\hline \multirow[t]{2}{*}{ S.No } & \multirow{2}{*}{\multicolumn{2}{|c|}{ Observation }} & \multicolumn{2}{|c|}{ Irrigated area } & \multicolumn{2}{|c|}{ Rainfed area } & \multicolumn{2}{|c|}{ Total } \\
\hline & & & & $\%$ & No of farmers & $\%$ & No of farmerc & or \\
\hline \multirow[t]{3}{*}{1} & \multirow[t]{3}{*}{ Age } & Young $(<30$ years $)$ & 18 & 14.4 & 18 & 14.4 & 36 & 14.4 \\
\hline & & $\begin{array}{l}\text { Middle (31-50 } \\
\text { years) }\end{array}$ & 80 & 64 & 75 & 60 & 155 & 62 \\
\hline & & Old (>50years) & 27 & 21.6 & 32 & 25.6 & 59 & 23.6 \\
\hline \multirow[t]{2}{*}{2} & \multirow[t]{2}{*}{ Education } & Illiterate & 102 & 81.6 & 110 & 88 & 212 & 84.8 \\
\hline & & Literate & 23 & 18.4 & 15 & 12 & 38 & 15.2 \\
\hline \multirow[t]{2}{*}{3} & \multirow[t]{2}{*}{ Family type } & Joint & 23 & 18.4 & 19 & 15.2 & 42 & 16.8 \\
\hline & & Nuclear & 102 & 81.6 & 106 & 84.8 & 208 & 83.2 \\
\hline \multirow[t]{3}{*}{4} & \multirow[t]{3}{*}{ Family size } & $\begin{array}{l}\text { Small (2-4 } \\
\text { members) }\end{array}$ & 57 & 45.6 & 48 & 38.4 & 105 & 42 \\
\hline & & $\begin{array}{l}\text { Medium }(5-7 \\
\text { members })\end{array}$ & 58 & 46.4 & 58 & 46.4 & 116 & 46.4 \\
\hline & & $\begin{array}{c}\text { Large (above } 7 \\
\text { members) }\end{array}$ & 10 & 8 & 19 & 15.2 & 29 & 11.6 \\
\hline \multirow[t]{5}{*}{5} & \multirow{5}{*}{$\begin{array}{l}\text { Land holding } \\
\quad \text { (acres) }\end{array}$} & Landless ( 0 acres) & 57 & 45.6 & 91 & 72.8 & 148 & 59.2 \\
\hline & & $\begin{array}{c}\text { Marginal (0.01-2.5 } \\
\text { acres) }\end{array}$ & 45 & 36 & 21 & 16.8 & 66 & 26.4 \\
\hline & & Small (2.51-5 acres) & 21 & 16.8 & 12 & 9.6 & 33 & 13.2 \\
\hline & & $\begin{array}{l}\text { Medium (5-10 } \\
\text { acres) }\end{array}$ & 2 & 1.6 & 1 & 0.8 & 3 & 1.2 \\
\hline & & $\begin{array}{c}\text { Large (above } 5 \\
\text { acres) }\end{array}$ & 0 & 0 & 0 & 0 & 0 & 0 \\
\hline \multirow[t]{2}{*}{6} & \multirow{2}{*}{$\begin{array}{c}\text { Main } \\
\text { occupation }\end{array}$} & sheep rearing & 64 & 51.2 & 93 & 74.4 & 157 & 62.8 \\
\hline & & $\begin{array}{l}\text { Sheep rearing } \\
\text { \&Agriculture }\end{array}$ & 61 & 48.8 & 32 & 25.6 & 93 & 37.2 \\
\hline 7 & Annual & Low ( RS. <55000 ) & 56 & 44.8 & 52 & 41.6 & 108 & 43.2 \\
\hline
\end{tabular}




\begin{tabular}{|c|c|c|c|c|c|c|c|c|}
\hline & $\begin{array}{l}\text { household } \\
\text { income }\end{array}$ & $\begin{array}{c}\text { Medium } \\
\text { (RS.55000-90000) }\end{array}$ & 64 & 51.2 & 65 & 52 & 129 & 51.6 \\
\hline & & High (RS.>90000) & 5 & 4 & 8 & 6.4 & 13 & 5.2 \\
\hline \multirow[t]{2}{*}{8} & \multirow{2}{*}{$\begin{array}{l}\text { Type of } \\
\text { farmer's } \\
\text { residence }\end{array}$} & Kutcha & 72 & 57.6 & 70 & 56 & 142 & 56.8 \\
\hline & & Pucca & 53 & 42.4 & 55 & 44 & 108 & 43.2 \\
\hline \multirow[t]{3}{*}{9} & \multirow{3}{*}{$\begin{array}{l}\text { Farmer's } \\
\text { religion }\end{array}$} & Hindu & 120 & 96 & 115 & 92 & 235 & 94 \\
\hline & & Christian & 5 & 4 & 10 & 8 & 15 & 6 \\
\hline & & Muslim & 0 & 0 & 0 & 0 & 0 & 0 \\
\hline \multirow[t]{4}{*}{10} & \multirow[t]{4}{*}{ Community } & OC & 4 & 3.2 & 5 & 4 & 9 & 3.6 \\
\hline & & BC & 108 & 86.4 & 84 & 67.2 & 192 & 76.8 \\
\hline & & SC & 10 & 8 & 19 & 15.2 & 29 & 11.6 \\
\hline & & ST & 3 & 2.4 & 17 & 13.6 & 20 & 8 \\
\hline \multirow[t]{3}{*}{12} & \multirow{3}{*}{$\begin{array}{c}\text { Sheep Farming } \\
\text { Experience }\end{array}$} & $<5$ Years & 26 & 20.8 & 24 & 19.2 & 50 & 20 \\
\hline & & 5-15 Years & 76 & 60.8 & 72 & 57.6 & 148 & 59.2 \\
\hline & & $>15$ Years & 23 & 18.4 & 29 & 23.2 & 52 & 20.8 \\
\hline
\end{tabular}


Whereas, $26.4 \%$ farmers had flocks with the range of $76-100$, about $24 \%$ were maintaining flocks with the range $25-50,14.4 \%$ had flocks above 100 and very few (3.2 percent) shepherds maintaining flock less than 25 in rainfed area. It was seen that the average flock size in irrigated area of the district was $66.36 \pm 2.32$ and in rainfed area, it was $73.62 \pm 3.0$.

These results indicated that the flock size was not constant and varied from flock to flock and from farmer to farmer. It has a direct influence on the overall income of sheep farming. Flock sizes are dynamic, and their increase/decrease is controlled by factors such as diseases, sales for urgent monetary requirements, grazing resources, labour etc.

Homegrown rams were found to be the major source of rams to the farmers (64.8 percent in irrigated area and 52.8 percent in rainfed area), followed by procuring the rams by means of exchange with the neighbors (32.8 percent in irrigated area and 44 percent in rainfed area). Whereas, very few farmers were purchasing rams from outside (2.4 percent in irrigated area and 3.2 percent in rainfed area).

Similarly, homegrown ewes were the source of ewes for the majority (93.6 percent in irrigated area and 92 percent in rainfed area) of the farmers selected in the study area.

While very few (6.4 percent in irrigated area and 8 percent in rainfed area) procured ewes for their flocks by means of purchase from others.

It clearly showed that within the flock selection of rams, though an unscientific way which may eventually reduce the flock performance due to inbreeding and the farmers were generally reluctant to share their breeding ram due to some socio-economic reasons and beliefs. Analysis on the socio- economic conditions and flock profile of 250 sheep farmers under field conditions in irrigated and rainfed areas in Krishna district of Andhra Pradesh revealed that sheep rearing was the main occupation of the respondents (51.2 and 74.4 percent) in both areas. Majority of the sheep farmers in both areas were Hindus and belonged to Backward Class followed by Scheduled Castes. Literacy rate in irrigated and rainfed areas were 18.4 and 12 percent, respectively.

Majority of the sheep owners in both areas were in the middle age group (64 and 60 percent). Nuclear family type dominated in both the areas. The mean sheep farming experience of farmers in irrigated area and rainfed area was $9.77 \pm 0.69$ and $12.05 \pm 0.88$ years, respectively. Majority of the sheep farmers in both areas were landless (45.6 percent and 72.8).

Among the total farmers, 12.8 percent in irrigated area and 8 percent in rainfed area owned single species of sheep alone.

The average flock size in irrigated and rainfed areas of the district was $66.36 \pm 2.32$ and $73.62 \pm 3.0$, respectively. The study indicated that the flock size was not constant and varied from flock to flock and from farmer to farmer and depended on many factors such as disease, sales for urgent monetary requirements, grazing resources, labour etc. Replacement stock from own farm was the main source of addition into flocks in both the areas.

\section{Acknowledgements}

The authors are grateful to Sri Venkateswara Veterinary University, Tirupathi for providing necessary facilities and financial support to carry out this research. The valuable help from Animal Husbandry Department, Government of Andhra Pradesh during the entire course of study is also duly acknowledged. 


\section{References}

Chandramouli, D., Subbarama Naidu, A., \& Sarjan Rao, K. 1996. Socio economic perspectives of small ruminant breeds in Nellore Region (AP). In Compendium of National Seminar on Small Ruminants Production and Post Production Systems, Current Status and Development, CLRI, Chennai, India (pp. 0406).

Chaturvedi, O. H., Sankhyan, S. K., Mann, J. S. and Karim, S. A., 2008. Livestock holding pattern and feeding practices in semiarid eastern region of Rajasthan. Indian Journal of Small Ruminants, 14(2), pp.224-229.

Chaturvedi, O. H., Tripathi, M. K., Mishra, A. S., Verma, D. L., Rawat, P.S. and Jakhmola, R. C., 2002. Land as well as livestock holding pattern and feeding practices of livestock in Malpura taluk of semiarid eastern Rajasthan. The Indian Journal of Small Ruminants, 8(2), pp.143-146.

Choudary, P. V., Ekambaram, B., Prakash, M. G. and Rajanna, N., 2013. Socio-economic characteristics and marketing attributes of Macherla Brown sheep farmers. Indian Journal of Animal Production and Management, 29(1/2).

Deshpande, S. B., Sabapara, G. P., Malik, P. K., Sadana, D. K., Singh, P. K., Gurmej, S. and Joshi, B.K., 2010. Indian Journal of Animal Sciences, 80(6), pp.575-577.

Geeta, M., Sunanda, K. and Bhavani, K., 1999. Karnataka-Sheep farmers. The Indian Journal of Small Ruminants, 5(2), pp.82-84.

Kuldeep, P., Karim, S. A., Sisodia, S. L. and Singh, V. K., 2006. Socioeconomic survey of sheep farmers in Western Rajasthan. Indian Journal of Small Ruminants, 12(1), pp.74-81.

Kumar, V., Singh, B. P., Tiwari, R., Kumar, S. and Goel, A. K., 2015. Socio-economic profile of goat farmers in Uttar Pradesh. Indian Journal of Small Ruminants (The), 21(2), pp.317-321.

Kushwaha, B. P., Mehta, B. S. and Kumar, S., 1999. Survey of Chokla sheep in farmers' flock. The Indian Journal of Small Ruminants, 5(1), pp.14-19.

Patil, D. S., Meena, H. R., Tripathi, H., Kumar, S. and Singh, D.P., 2012. Socio-economic profile of sheep reared Dhangar pastoralists of Maharashtra, India. J Rec Adv Agri, 1(3), pp.84-91.

Rajanna, N., Mahendar, M., Thammi, R. D., Raghunadan, T., Nagalashmi, D. and Sreenivasarao, D., 2012. Socio-economic status and flock management practices of sheep farmers in Telangana region of Andhra Pradesh. Veterinary Research, 5(2), pp.3740.

Rao, K. A., Rao, K. S., Rao, S. J., Ravi, A. and Anitha, A., 2013. Int. J. Agric. Sci. Vet. Med, 1, pp.131-144.

Sireesha, K., Prasad, R. M. V., Rao, J. S. and Jayalakshmi, P., 2015. Socio economic status and constraints faced by shepherds in Guntur district of Andhra Pradesh. Indian Journal of Animal Production and Management31 : 4345.

Snedecor, G. W. and Cochran, W. G., 1994. Statistical Methods 8th edn (New Delhi: Affiliated East.

Tanwar, P. S., Vaishanava, C. S. and Sharma, V., 2008. A study on socio-economic aspects of goat keepers and management practices prevailed in the tribal area of Udaipur district of Rajasthan. Indian Journal of Animal Research, 42(1), pp.71-74.

Thiruvenkadan, A. K., Karunanithi, K. and Purushothaman, M. R., 2004. Socioeconomic status of the Mecheri sheep farmers and economics of rearing under farmer's management system. The Indian Journal of Small Ruminants, 10(1), pp.1-6.

\section{How to cite this article:}

Sai Satish Raju Sarikonda, Asha Latha Peeka, Sudhakar Kaza and Raja Kishore Konka. 2021. A Study on Socio-Economic Aspects and Flock Composition of Shepherds in Irrigated and Rainfed Areas in Krishna District of Andhra Pradesh, India. Int.J.Curr.Microbiol.App.Sci. 10(05): 730-737. doi: https://doi.org/10.20546/ijcmas.2021.1005.082 